\title{
İletişim Aracı Olarak Dans: Ya da dans bir iletişim şekli midir?
}

\section{Dr. Öğr. Üyesi Gökçe SÖNMEMiş}

Mimar Sinan Güzel Sanatlar Üniversitesi

Sahne Sanatları Bölümü/Bale Anasanat Dalı

gokce.sonmemis@msgsu.edu.tr

ORCID: 0000-0002-3855-0169

\begin{abstract}
Öz
Bu makalenin önermesi; dansın önemli bir iletişim aracı olduğu ve duyguları, düşünceleri ifade ederken beden dilini, duruşları, pozları ve hareketleri bir araç olarak kullandığı yönündedir. Çağlar boyunca insan topluluklarının farklı amaçlar için dans ettiği gözlemlenmiştir. Insanlar kadim zamanlardan beri dans etmiş olsalar da "insan neden dans eder?" sorusunun cevabı henüz tam olarak verilebilmiş değildir. Bu konu üzerine farklı tezler olmasına rağmen, insanın duygularını ifade edebilmek için dans ettiği tezi, en kabul gören tezlerden biridir. İnsanlar dini, sosyal, sanatsal hatta medikal tedavilere paralel ilerleyen hareket terapisi olarak dans edebilirler. Dans etmedeki nedenler farklı olsa da ana fikir çoğunlukla bir hikâye anlatmak, iletişim kurmak üzerinedir. Dini amaçla yapılan danslarda insan, kendisinden daha üstün bir varlık ile iletişim kurmaya çalışırken, sosyal veya sanatsal amaç ile yapılan danslarda ya kendi iç dünyasıyla ya da çevresindekilerle iletişim kurmayı hedefler. Bu makale, dansın iletişim yönünü ana hatları ile ele almayı amaçlar, ilgili kaynakların ve bilimsel araştırmaların incelenmesi, analizler ve literatür taraması ile elde edilen veriler doğrultusunda, dansın bir iletişim şekli olup olmadığını irdeler. Dans alanında Türkçe kaynakların sınırlı olması sebebi ile bu makale literatür azlığını bir nebze gidermeyi ve dansın iletişim yönü hakkında genel bir fikir vermeyi hedefler.
\end{abstract}

Anahtar Kelimeler: dans, iletişim dili, kültür. 


\title{
Dance as a Tool of \\ Communication: Or is dance a form of communication?
}

\begin{abstract}
This article argues that dance, as an essential medium of communication, uses body language, posture, poses and movements as tools to express and convey thoughts and feelings. It has been observed that through the ages human communities and cultures have used dance for a variety of purposes. Although people have been dancing since ancient times, we have not yet been able to answer the question as to why people dance. There are a wide range of theses on this subject, but the most widely accepted of these is that people dance to express their feelings. People can dance for religious, social, artistic or even medical purposes like movement therapy that works in accordance with certain medical treatments but the main idea within dance has mostly been to communicate as a form of self expression, as a mode of storytelling and as a means to share a message. In religious dances, people aim to communicate with a being higher than themselves, whereas in dances performed for societal and artistic purposes people aim to communicate with others or with their inner self. This article aims to outline the communicative aspect of dance through the examination of relevant sources and scientific research. In line with the data obtained through analyses and literary review, this article will examine whether dance is a form of communication or not. Due to the limited resources in Turkish in the field of dance, this article aims to serve as a starting point of discuss and study and begin to remedy the lack of literature on dance in Turkey and give the Turkish people a general idea on the communicative elements of dance.
\end{abstract}

Keywords: dance, language of communication, culture. 


\section{arts}

\section{Gíiş̧}

Dans ile ilgili yapılan araştırmaların büyük çoğunluğu; metotların incelendiği dans tekniği, tekniğin uygun yaşta, uygun miktarda öğretilmesini sağlayan dans dersleri veya dansın kültürle olan ilişkileri ile dansçı yaralanmalarını önlemeye ve performans geliştirmeye yönelik dans tıbbı alanında yapılmış çalışmalardan oluşmaktadır. Bu araştırmanın amacı ise dansla ilgili davranışı anlamak, dansın nasıl iletişimsel bir fenomen olduğunu ve dansın, sözlü olmayan davranış yoluyla mesaj gönderip almak için nasıl kullanıldığını anlamaya çallşmaktır.

Dans, iletişim kavramı kapsamındaki çoğu eylemi bünyesinde barındırı; fiziksel hareketler yoluyla ruh halimizi değiştirebilir, bir çekim gücü işlevi görebilir, algıyı etkileyebilir, yeni bir duygu uyandırabilir. Bu paralelliklerin yanı sira her iki olgunun tarihinin de insanlık kadar eski olduğu söylenmektedir. Illkel insanın dansı iletişim aracı olarak kullandığı tezi yaygın olarak kabul edilmektedir. Ilkel insanlar dansı sadece kendi aralarında iletişim kurmak için değil, aynı zamanda doğa ve doğaüstü ile de iletişime geçmek için kullanmışlardır. Dans ilkel ritüellerin vazgeçilmez unsurlarından biri olmuş ve toplulukların belirlediği kalıplar, kurallar çerçevesinde gelişmiştir. Bu dönemlerde dans toplumsal bir eylem olduğu için mesleki ya da sanatsal türden bir uğraş değil sıradan bir uğraştı.

Illkel dönemlerden beri varlığını koruyan dansın, yaşanan kültürel değişimlerle birlikte izleyici için sergilenmeye başlamasıyla sanata dönüştüğü kabul edilmektedir. Dans her ne kadar en eski sanat dallarından biri olarak görülse de günümüz anlayışı ile sanat halini alması $X V$. yüzylın sonlarında saray eğlencelerinin içinden evirilen bale ile başlar. Balenin ortaya çıkışına kadar dans, sanat biçiminden daha çok bir eğlence, sosyalleşme aracı olarak görülmüş ya da ritüellerin içinde tamamlayıcı unsurlardan biri olarak kullanılımışır.

Dünyada çok fazla dans türü olmasına karşın dans kavramı insanların aklında genellikle içinde yaşadığı toplumun kabul ettiği, kültürel yapısına uygun, kendi hoşuna giden estetik formlara en yakın olan dans türüyle canlanır. Belki de dansı ifade etmek ve açıklamaktaki esas zorluk, simgesel ve harekete dayalı anlatım dili olan bir eylemi, sözcükler veya yazı ile açıklamaya çalışmakıtır. Her ne kadar dans 
içerdiği iletiyi daha iyi ifade edebilmek için sözcükler yerine bir diğer evrensel dil olan müzikten yardım alsa da esas iletim aracı müzik odaklı değil beden ve duygu odaklıdır. Dans özünde hareket temelli bir ifade şeklidir, edebiyatta sözcüklerin işlevi ne denli önemliyse danstaki hareketler de aynı oranda önem taşımaktadır, dolayısıyla onu açıklayabilmenin en iyi yollarından biri belki de dansı yine dans ile anlatmaktır.

Araştırmalarında gösteri sanatlarına da odaklanan antropolog Adrienne Lois Kaeppler de dansın tanımlarını yaparken iletişim özelliğinin yeterince vurgulanmadığını savunur (Kaeppler, 2006, s. 406):

Dans, genellikle müzikal sesle bazen bir șiirle, görsel hareketli ve estetik görünüşlerin birleştiği, kulağa ve göze hitap eden kompleks bir iletişim formudur. Dans sosyal ve dinsel temaları taşıyan, kutlama, eğlence ve dinsel törenlerin anlamını içeren kültürel anlayışın sembolüdür. Dans insanların yer ve zaman içindeki hareketleridir. Dansta iletişimi sağlayabilmek için bu kültürel olayın seyirci tarafından anlaşılması gerekmektedir. Dansın pek çok tanımı yapılmışıır. Fakat hiçbiri dansın iletişim özelliğini içermemiştir. Sadece birkaç istisna yazar, dansın iletişim etkisinden ya da onun öyküsel ve taklitsel dansın içerdiği hareketlerin potansiyelinden bahsetmiştir. Sonuç olarak tüm bu iddialara rağmen dansın iletişimsel fonksiyonunun kesin tanımı ve araşıııası halen başlangıç seviyesindedir.

\section{İletişim Nedir?}

İletişim Türkçeye son elli yıldır girmiş bir sözcüktür, daha önce var olan komünikasyon sözcüğünün yerine kullanılmaya başlanmıştır. Illetişimin batı dillerindeki karşılı̆ı olan "communication" sözcüğünün kökeni Latince "communis" ve "communicare" sözcüklerinden gelmektedir. Communis ortak, umumi, paylaşılan; communication ise paylaşmak, bağlantılı olmak, yardımlaşmak, yaygınlaştırmak anlamlarını taşımaktadır (Communication, 2020). Iletişim kavramının çok fazla tanımı olmakla birlikte bu kapsamdan bakıldığında genel olarak bireyler arasındaki bilgi paylaşımı olduğu ileri sürülebilir. Daha geniş bir kapsamda ise iletişim; fikirlerin, görüşlerin, duyguların, haberlerin, bilgilerin, kavramların, hayal gücünün bir başka değişle anlatımak istenen tüm içeriğin çeşitli yollarla başka birine aktarılmasıdır, dolayısıyla iletişimin bireyler ve nesiller arasındaki içerik paylaşılma süreci olduğu söylenebilir (Özgüven, 2010).

İnsan biyolojik bir varlıktır ama varlığını sürdürebilmesi için diğer insanlara 


\section{arts}

yani topluma gerek duyar. Bu gereklilik insanın biyolojik varlığının yanı sıra onun aynı zamanda toplumsal bir varlık olduğu gerçeğini de ortaya koyar. Toplumsal yaşamın en temel gereksinimi ise kuşkusuz iletişimdir öyle ki iletişim kavramı, insanlığın yaşamsal gereksinimlerinin ardından ilk sırada yer alan bir önceliği elinde tutmaktadır (Akgül, 2006, s. 11).

Var olma mücadelesi içinde toplumsallaşma ihtiyacı duyan insanın toplum olma ve kültür üretimi için elinde olan en temel araçlardan biri de dildir. İnsan ve dil kavram olarak birbirinden ayrı düşünülmesi mümkün olmayan iki unsurdur ve birbirlerine güçlü bir sebep sonuç ilişkisiyle bağlıdırlar. Bu anlamda dil bireyler arasında iletişimi kuran en güçlü araçtır, bilimsel ifadesiyle kod ya da göstergeler sistemidir ve sistemin birincil işlevi iletişimdir (Öztürk, 2014, s. 58).

Illetişim kavramı değişik kaynaklarda karşımıza birbirlerinden farklı tanımlarla çıksa da ana fikir temelde çok fazla değişiklik göstermez. Bu ortak ana fikirden baktığımızda ise iletişimi duygu, düşünce ve bilginin mümkün olan en az kayıpla ve bulunacak en uygun yolla karşı tarafa aktarıması olarak tanımlayabiliriz. İletişim sadece insanlara özgü bir olgu olmamakla birlikte, insanları iletişim konusunda diğer canlılardan ayıran temel bir fark vardır. Bu büyük fark, insanın yarattığı simgeler ve semboller aracılığıyla duygu, düşünce veya bilgiyi biriktirebilmesi ve biriktirdiği bu muhtevayı mümkün olan en az kayıp ile aktarabilmesidir. Şüphesiz ki insanlık tarihi boyunca süregelen bu aktarım, aynı zamanda bilgi birikimine, kültür oluşumuna ve tarihin akışını değiştirecek boyutta bir etkiye de büyük ölçüde katkı sağlamıştır.

Belki de insanı insan yapanın, bilgi ve düşüncelerin mümkün olan en $a z$ kayıp ile aktarma becerisi olduğunu söylemek eksik ama doğru bir yaklaşım olabilir. İnsanlık edindiği tecrübe ve kültür birikimini nesillerce aktararak, basit teknolojilerden günümüz toplumuna kadar uzanan bir yolu da arkasında bırakmıştır.

Dans, bir anlamda iletişimin sanatsal boyutta varoluşudur. Toplumların ortak değerlerinden biri olan dans sergilendiğinde; sınıf, dil, din, ırk ayrımlarını ortadan kaldırabilen güçlü bir iletişim aracı da olabilmektedir. Dans ortaya çıktığından beri hiç kuşkusuz bireylerin, toplumların, kültürlerin iletişimi için kurulan köprülerden biri olmuştur. Dansçının dansçıyla ya da dansçının izleyiciyle iletişiminin binlerce yıllık 
geçmişi aslında hep var olan bu sağlıklı ileti aktarımını işaret etmektedir (Akgül, 2014, s. 15).

Günümüz toplumunda iletişim temelde değişmese de iletim şekli ve yolları, ilerleyen teknolojiler sayesinde oldukça gelişmiştir. Artık iletişime konu olan veri, kaynaktan alıcıya mesafeler ne kadar uzak olsa bile saniyelerle ölçülebilen hızlarla ulaşabilmektedir. Bu hıza ayak uydurmaya çalışan insan, hiyerogliflerden emojilere evirilen bir zaman diliminde, uzun yazllar yazmak yerine basit ama anlaşılır şekiller yolu ile iletişimini sembolik bir boyuta taşıma çabasındadır. Düşünceme göre dans da en başından beri böyle bir çabayı varlığında taşımaktadır.

Dansçı, dansı kullanarak kendini anlatmaya çalışır. Gerek duygulanımını ve gerekse bütün sorunlarını bedenini bir enstrüman olarak kullanarak dışa vurmaktadır. Bu anlamda dans bireyin toplumla iletişim kurması ve pekiştirmesine ve böylelikle sosyalleşmesine ciddi katkı sağlamaktadır (Eroğlu, 2017, s. 224).

İletişim kavramı içinde sözsüz iletişim de en az sözlü iletişim kadar önemli ve geniş bir yere sahiptir. Bu konuda yapılmış araştırmaların ortak çıkarımlarından birisi de sosyal etkileşimin büyük bölümünün sözel olmayan davranışlardan, hareketlerden ve görsel uyaranlardan kaynaklandığıdır. Dansın sözlü olmayan, harekete dayalı, sembolik bir iletişim biçimi olduğu düşünüldüğünde, aynı zamanda benzersiz bir sosyal etkileşim aracı olduğu da ortaya çıkmış olur.

\section{Dans Nedir?}

Dans kelimesi Almanca, Fransızca, İngilizce gibi dillerde Tanz, Tanse, Dance şeklinde ifade edilmektedir. Türkçede "Dance"in karşılığı "Raks"tır. Arapça raks sözcüğünden Türk diline geçmiş bulunan bu sözcük Arapçada, "sıçrayarak oynama" anlamındadır (Eroğlu, 2017, s. 218). Günlük dilde dans, raks ve oynamak dans etmeyi betimlemek için kullanılan sözcüklerdir, bununla birlikte farklı anlamlar içerdikleri de bilinir. Anlam farklııklarının önemli bir nedeni de kültürel çeşitliliktir ve bu çeşitlilik iletişim söz konusu olduğunda yönlendirici olmaktadır. Türkçede bu sözcükler arasından dansı ifade etmek için seçilip kullanılan sözcük aynı zamanda öznel bir duyguyu veya düşünceyi de dile getirmektedir. Örneğin dans kavramı estetik bir değer yüklüyken veya estetik bir kaygı ile icra edilmesi fikrini taşıyabilirken, 


\section{arts}

oynamanın estetiğe dikkat etmeden daha ziyade müzik eşliğinde ve müziğe uygun hareket etme niyetini taşıdığını söyleyebiliriz. Raks ise dansla eşanlamlı bir kelime olduğu halde dilimize giriş kökenleri itibariyle genellikle algılarda farklı çağrışımlar oluşturmaktadır; dans bałı üslubunda, raks ise doğu üslubunda icra edilen dansları akla getirmektedir.

Dans kavramını açıklamayı hedefleyen bazı ortak tanımlar olmasına karşın "Dans nedir?" sorusunun kesinleşmiş net bir yanıtı yoktur. En sık karşılaşılan tanımlardan biri dansı, insan bedeninin normal kullanımı dışındaki bir amaç için zaman ve mekânda ritmik kalıplar oluşturacak şekilde hareket etmesi olarak açıklamaya çalışır. Bir başka yaygın tanım dansın amaçlarını da kapsamına almayı hedefler bu tanıma göre dans: Bedenin müzik veya bir ritim eşliğinde, melodiye uyumlu olarak salındığı büyü, ritüel, tedavi şekli, sanat veya bütün bunların dışında yalnızca bir ifade türüdür. Bu tür ve benzeri açıklamalar dansı tam olarak tanımlayamasa da dans hakkındaki genel fikri ortaya koymaktadır. Bununla birlikte dans o denli yaşamın bir parçası olmuştur ki tanımlama söz konusu olduğunda ve çok özel bir dans türünden bahsedilmiyorsa yapılan tanımların çoğu dansa dair genel özellikleri zihinde uyandırmaya yeterli olabilmektedir.

Günümüze ulaşan en eski tanımlardan biri de Aristoteles'e aittir. Bu tanıma göre taklit isteği insanlarda doğuştan vardır ve sanatların büyük bir kısmı da taklittir. Dans, ses aracılığı ile taklit eder, ritimden veya harmoniden yararlanır. Dans eden kişiler ritmik beden hareketleriyle daha önce gözlemledikleri karakter özelliklerini, tutkuları ve hareketleri taklit ederler (Aristoteles, 2017, s. 35-36).

Literatürde dans ve iletişim ilişkisini vurgulayan tanımlar da vardır. Gürbüz Aktaş'ın tanımı bu ilişkinin altını oldukça belirleyici bir biçimde çizmektedir. Aktaş'a göre dans, insanın kendi duygu ve düşüncelerini anlatabilmesi ve toplumla iletişim kurabilmesi için anlam içeren hareketler topluluğunun meydana getirdiği estetik ve ritmik özelliğe sahip bir yaratıcılığın sonucu olan fiziksel ve duygusal davranıştır (Aktaş, 1999, s. 4).

Dans araştırmaları yapan bilim insanları, dansın toplumda iş birliğini ilerletmek, eşleri ve araçları seçmek için bize fikir verdiği tezini ortaya koyar. Yapılan 
araştırmalardan elde edilen veriler bize insan neden dans eder sorusu hakkında tahmin yürütebileceğimiz bazı fikirler verir. Kökeni araştırıldığında, her ne kadar dansın tam olarak ne zaman başladığına dair kesin bir belgeye veya kanıta rastlanmasa da arkeolojik bulguların incelenmesi sonucunda dans hakkında yorumlara ve spekülatif tespitlere ulaşılmıştır. Hindistan'da bulunan Bhimbetka Kaya Barınaklarındaki otuz bin yıllık taş devri kaya resimlerinde bulunan figürler, erken dönem dans kanıtı olarak sunulmakta ve kabul görmektedir.

Bhimbetka ve diğer kaya, mağara resimlerine baktığımızda Taş devri insanlarının hayatta kalmak için birçok faaliyette bulunduğunu ve çeşitli beceriler geliştirdiğini görebiliriz. Avlanma, yiyecek toplama, alet üretme, giysi yapımı gibi pek çok hayatta kalmayı gerektiren faaliyetlerin yanında yaşamsal gerekliliği olmayan, karşılıksız bir enerji israfı gibi görünen dansı da görürüz. Çizgisel ve dairesel formlarda resmedilen bu dansların günümüzde de pek çok dansa yansıdığını görebiliyoruz. Araştırmacı yazar Barbara Ehrenreichr, Sokaklarda Dans isimli kitabında konuyla ilgili fikirlerini özetle şöyle açıklıyor:

\begin{abstract}
Dans etme ihtiyacının insan toplumlarının temeli olduğunu kabul etmek gerekiyor. Dansın paleolitik çağ olarak adlandırılan taş devrine kadar uzandığı ve önemli bir yer tuttuggu gerçeğini destekleyen arkeolojik bulguları görebiliyoruz. Bu bulgular ışı̆̆ında insanların yerleşik hayata geçmeden, doğal olarak yazılı aktarımı da bulamamış oldukları dönemlerde, yaşam tarzlarına göre dans ettiklerini ve bu danslarının mağara duvarlarına kaydedilmeye değer etkinlikler arasında olduğunu kavradıklarını veya düşündüklerini varsayabiliriz (Ehrenreich, 2006, s. 22).
\end{abstract}

Ortaya çıkışını, nedenini, kökenini henüz tam olarak tespit edebilmek mümkün olmasa da dansın insanlık kadar eski olduğu yadsınamaz bir gerçektir. Bilim İnsanlarının, ilkel insan modellerine dayandırdığı dans tezleri mevcuttur. Bu tezler arasında en çok kabul gören iki tez ön plana çıkmaktadır. Bunlardan biri, ilkel insanın avlayacağı hayvanları taklit ederek onların becerilerine kavuşma ve savaşta karşı tarafa gücünü göstermek için dans ettiği tezidir. İkincisi ise karşı cinsi etkilemek, baştan çıkarmak, eş bulabilmek için insanın gelişimine paralel olarak evirilen, sağlıklı ve güçlü olduğunu göstermek için dans ettiği tezidir. Doğada da pek çok hayvanın karşı cinsi etkilemek için dansa benzer devinimler sergilediği gözlemlenir.

Manchester Üniversitesi, Psikoloji Bölümü Araştırmacıları insanların dans etmelerinin psikolojik nedenleri dışındaki faktörleri de araştırmış ve bir tez olarak dansın 


\section{arts}

biyolojik bir boyutu olduğunu da öne sürmüşlerdir. Araştırmacılar tezlerini artan ses seviyesiyle ilişkili olarak iç kulakta oluşan yapısal hareketliliğe dayandırmaktadırlar. Insan kulağı 40-50 desibel aralığındaki ses seviyesini orta ses seviyesi olarak algılamaktadır, araştırmacıların hipotezine göre dinlenen müziğin desibeli arttıkça iç kulaktaki devinim de farkllık gösterip denge sistemini uyarmakta, kişi de bu doğrultuda hareketlenmekte, hareketlilik de dansa dönüşmektedir. Bu hipotezi destekleyecek bulgu olarak da eğlence mekanlarında çalınan yüksek seviyeli müziğe uyup dans etmeye başlayan insanlar gösteriliyor (Arıkan' dan aktaran Tercan, 2016, s. 33). Dans etmeyi insanın biyolojik boyutuyla ilişkilendiren söz konusu bu hipotez günümüz olanaklarıyla kanıtlanamamaktadır dolayısıyla ortaya atılan bu görüşe araştırıması gereken bir düşünce olarak bakmak durumundayız.

Varlığı insanlık tarihinin başlangıcına dayanan dans hakkında bu kadar az bilimsel bilgiye sahip olmamızın sebeplerinden biri de dans hakkında yapılan akademik çalışmaların nispeten yeni başlamış olmasıdır. 1965 yıında kurulan CORD (Congress on Research in Dance) ile dans alanında araştırmalar yapılmaya başlanmıştır. İlerleyen yıllarda dans ve dansçılar hakkında bilimsel veriler toplanmaya başlanmış, ortaya çıkan bilimsel ilkeler de dans ve dansçılar için kullanılmaya başlanmıştır. Önceleri amaç dansçıların performansının artııııması, yaralanmaların azalması ve sağlıklı bir iyileşme süreci olmuşken, zamanla toplanan bu veriler dansın bilimsel yönünü de şekillendirmeye başlamıştır. Dans bilimi kavramı son yirmi yılda hızla gelişmiş, akademik bir disiplin olarak lisans ve yüksek lisans düzeyinde bilim dünyasındaki yerini almıştır.

Dans hekimliğinin ortaya çıkıp gelişmesi de aynı dönemlere denk gelmektedir. 1990 yılında bir grup dans hekimi, dans eğiticisi, dans bilimcisi ve dansçı tarafından Uluslararası Dans Tıbbı ve Bilim Birliği kurulur (International Association for Dance Medicine \& Science - IADMS). Bu organizasyon, düzenlediği dünya çapında konferans ve kongrelerle dans tıbbının gelişmesine önemli katkılar sağlamıştır.

Dans tıbbının ortaya çıkışı tedavi edici özelliğinin yanı sıra bilimsel verilere dayanarak önerdiği ek çalışmalarla dansçıların tekniklerinin de gelişmesine önemli bir destek sağlamıştır. Özellikle günümüzde sahne performansı değerlendirilirken dansçıların izleyiciyle sanatsal/duygusal bağ kurma becerilerinin de gözetildiğini 
düşünürsek bu desteğin önemi yadsınamaz bir hal almaktadır. Dans tıbbı, teknik zorluğu çok yüksek olan hareketlerin daha fazla dansçı tarafından doğru ve eskiye göre daha az zorlanarak yapılabilmesine olanak sağlamıştır. Bu da dansın mesajını izleyiciye daha güçlü bir şekilde aktarmanın yolunu açmıştır.

Diğer taraftan önceleri bazı özel hareketleri çok az sayıda dansçı başarabilirken, bugün dans tıbbının getirileriyle aynı zor hareketleri gerçekleştirebilen dansçıların sayısı çoğalmaya başlamıştır. 1893 tarihinde Cinderella balesinde, İtalyan balerin Pierina Legnani tarafından ilk defa yapılan 32 fovettés en tournant isimli ve pointe üzerinde hiç durmadan otuz iki tur olarak uygulanan bale hareketi olağanüstü bir beğeni kazanmıştı ama bu hareket 1990'lara kadar sadece bazı başarılı baş dansçılar tarafından yapılabilmişti. Günümüzdeyse dans tıbbının bilgileri ışığında uygulanan ek çalışmalarla artık profesyonel bale eğitimi alan pek çok dansçı 32 fovettés en tournant hareketini genç yaşlarda ve başarıla yapabilmektedirler.

Belki de dansı tanımlarken; başlangıcından günümüze kadar varlığını koruyan ve gelişimini insanlığın gelişimine paralel olarak sürdüren, önce sanat alanında ardından bilim alanında yerini alarak varlığını daha da güçlendiren, insanın toplumsal yaşamının bir parçası olarak kabul etmek işimizi kolaylaştıracaktır.

\section{Dans ve İletişim}

Dans anlayışının sınırları çevresinde karşımıza iki ana problem çıkar. Bu problemlerden ilki, dansın sadece insan faaliyeti olup olmadığı veya insan olmayan canlılara da dayandırılıp dayandıııamayacağıdır; ikincisi ise, dansın yakın ilişki içinde olduğu diğer hareket temelli aktivitelerden ayrılma problemidir. Her iki problem de zaman ve mekân içinde vücudun yaptığı kalıplaşmış hareketlerin sonucu oluşan dans eylemi üzerinde ortaya çıkar. Dansın oldukça basit bir temel araca, sadece insan vücuduna dayanması, bizi insan ve primatların dans edişleri arasında paralellik çizmeye; kuşlar ve arıların dans edişlerinden bahsetmeye götürür (Royce, 1980, s. 3).

Bilim insanları uzun zamandır sadece insanların müzikle eş zamanlı hareket edebileceğini düşünüyorlardı. İnsana en yakın genetik özelliklere sahip olan şempanzeler bile müzikle eş zamanlı hareket etme becerisine sahip değildirler. 


\section{arts}

Insanlarla birlikte yaşayan ve evrimleşmiş olan, insanlar tarafından eğitilen köpekler veya kedilerde de müzik ile iş zamanlı hareket etme becerisi yoktur. Fakat San Diego'daki Neurosciences Enstitüsü'nde araştırmacı olan Aniruddh Patel'in Kakadu papağanı ile yaptığı denemelerde dikkat çekici sonuçlar ortaya çıkar.

Current Biology dergisinde yayınlanan sonuçlara göre, papağanın müzikle eş zamanlı hareket ettiği ortaya konmaktadır. Yapılan deneylerde araştırmacıların müziği yavaşlattığında veya hızlandırdığında papağanın da hızını müziğe göre ayarladığı gözlemlenir. Dans etmek, karmaşık sesleri yeniden üretebilecek bir beyin gerektirir diyen Patel, araştırmalarının sonucunu; maymunlar ve köpeklerin aksine, papağanların ve insanların dans edebilmelerinin nedenini, sesleri öğrenebilmelerine ve taklit edebilmelerine bağlar. İsitsel ve motor beceriler arasında iş birliği olmasını zorunlu kılan bu biyolojik bütünlük sayesinde sesleri duyabilme ve onları taklit edebilme yeteneği gelişmiştir. Doğada çok nadir rastlanan ses taklidi yeteneği insanlar dışında yunuslar, foklar ve ötücü kuşlar arasında görülmektedir, çoğu primat da dahil olmak üzere türlerin büyük çoğunluğu bu beceriye sahip değillerdir (Patel vd., 2009).

Harvard Üniversitesi Psikoloji Bölümü doktora öğrencisi Adena Schachner ve meslektaşları Patel'in fikrini araştırmak için internet veri tabanında sistematik bir tarama yaparak dans eden hayvanların videolarına ve sahiplerine ulaşılar. Patel'in hipotezini destekleyen birçok sonuca ulaşan Schachner ve meslektaşları bulgularını Current Biology dergisinde yayınlamışlardır. Bu sonuçlara göre kedi köpek gibi evcil hayvan sahipleri hayvanlarını dans ettirebilmek için harcadıkları yoğun çabalara rağmen sonuç alamıyorlardı. Kedi ve köpekler dans etmek bir yana, müzikle eş zamanlı hareket bile edemiyorlardı. Oysa bazı papağan sahipleri hiçbir çaba harcamadıkları halde bir gün kuşlarının, tesadüfen çalan bir müzik eşliğinde, kendiliğinden müzikle uyumlu hareketler yapmaya başladıklarını ifade ediyorlardı.

Ses taklitçisi kuşların vahşi doğada bu becerini kullanmak için belirgin bir alan olmadığı bilinirken, herhangi bir melodiye doğal olarak eşlik edebilme yetenekleri varmış gibi görünüyor. Patel "Dansın bir kısmı sesi taklit etme yeteneğimizin bir yan ürünü olarak ortaya çıktı." diyor. "Ses taklidi olmadan bir ritmi yakalayamazdık." diyen Patel'in teorisi, beynin motor sistemi ile işitsel korteks arasındaki yakın bağların dans etme yeteneğimizin temelini oluşturduğu yönünde (Patel vd., 2009). 


\title{
$\operatorname{arts}=$
}

Dansın harekete eşdeğer olduğu ve hareketin evrensel olduğu gibi önermelerden yola çıkıldığında; dansın da evrensel olduğu, tüm sanat türlerinin atası olduğu, insanın dil kullanımını öğrenmeden önce dans ile anlaştığı kabul edilen yaygın fikirlerden bazılarıdır. İlkel insana baktığımızda, dans dinsel ve büyüsel bir anlam da taşımaktadır. Ritüellerde yapılan savaş, av, bolluk, ölüm, erginlik gibi danslar, aslında doğaüstü güçler ile iletişim amacı gütmektedir. Okült, mistisizm ve metafizik hakkında araştırmalar yapan yazar Ted Andrews büyüsel dans için şunları söylemektedir (Andrews'dan aktaran Altunay, 2014, s. 111 ):

\begin{abstract}
Büyüsel şekilde dans etmeyi öğrenirken, bir iç enerjiyi ifade etmek için bir dış biçimi kullanııı. Fiziksel ifadeleri iç gerçekliklerle uygulamayı öğreniriz. Bu fiziksel hareketler iç ruhsal enerjilerimizi uyandırır ve dışarı çıkartırlar. İster sezgisel ister yaratıcı ister koruyucu ister iyileştirici olsunlar farklı hareketler farklı enerjileri harekete geçirirler. Duruşlar içimizdeki kutsallıkla, fiziksel bir iletişim yoludur. Birçok duruş ve pozisyon büyüsel güçlerle bir temas kurabilmek için hayvanları ve doğayı taklit eden bir ritüelden doğmuştur.
\end{abstract}

Illk insanların doğaya öykünerek yaptığı dans ritüellerinde hep bu büyüsel etkinin izlerini görebiliriz. Aslında bu izlere sadece ilkel insanın dansında değil günümüzde dansın en sofistike formu olarak kabul edilen balede de rastlarız.

Dans aynı zamanda evrenin varoluşuyla da ilişkilendirilir. Hint mitolojisindeki üç ana tanrıdan biri olarak kabul edilen Şiva, diğer özelliklerinin yanı sıra dans etmesiyle tanınmaktadır, bu nedenle isimlerinden biri dansın kralı anlamına gelen Şiva Nataraja'dır. İnanışa göre Şiva Nataraja, tandava adı verilen dansı ederek dünyayı yaratır fakat bu yaratış tek seferlik bir eylem değildir. Şiva dünyayı yaratır, bir müddet gözetir, sonra yok eder, ardından dünyayı tekrar yaratıp aynı sarmalı yineler. Bu şekilde süregelen bir kozmik döngü vardır, bu döngü tandava dansı ile kontrol altındadır ve sonsuza dek sürmektedir (Bilican, 2019).

Çağlar boyunca dans sadece tapınmak ve ritüel amaçlı kullanılmamış aynı zamanda toplum içinde birliği de artırmak için kullanılmıştır. İnsanlar genel olarak dans etmek için başka bireylerin varlığına intiyaç duyarlar. Bir kutlama gereği veya sadece hoşça vakit geçirmek için bile olsa dans sosyal bir olgudur. İnsanlar grup halinde dans ederken hareketlerini birbirlerine uydurarak senkronize olurlar işte bu durum dansın sosyal bir iletişim aracı olma sonucunu doğurur.

Akademisyen Scott Wiltermuth, antropologların ve sosyologların, eş zamanlı 


\section{arts}

faaliyet içeren ritüellerin kendilik ve grup arasındaki psikolojik sınılları zayıflatıp, olumlu duygular üretebileceği iddiası üzerine üç deney içeren bir araştırma yapmıştır. Araştırmasının sonucu olarak grup üyelerini birbirleriyle eş zamanlı hareket ettikleri dans türü eylemlerin grup içindeki iş birliğini arttırdığını, grup üyeleri arasındaki sosyal bağllığı güçlendirdiğini gözlemlemiştir (Wiltermuth, 2009).

Psikolog ve dansçı Ahalya Hejmadi, dansın uluslar ve kültürler arası bir iletişim aracı olup olmadığını öğrenmek için bir deney geliştirir. Hejmadi tasarladığı deney için tarihi kesin olarak belirlenemese de iki bin yıldan daha eskiye dayanan, klasik Hint dansını ve tüm performans sanatlarını tanımlayan 36 bölüm, 6000 şiirsel tanımdan oluşan bir Hint metni olan "Natya Shastra"dan yararlandı. Hejmadi, Natya Shastra metinlerinden derlediği on duyguyu canlandırmak için bu duyguları tasvir eden hareket ve figürlerden oluşan bir danstan yola çıkar. Metinlerde geçen öfke, iğrenme, korku, kahramanlık, mizah-eğlence, aşk, barış, üzüntü, utanç ve merak olmak üzere on duyguyu seçer. Seçilen bu on duygunun her birini duygunun üç farklı versiyonu olmak kaydıyla anlatan 30 figür ve bu 30 figüre ek olarak hiçbir duygu ifade etmeyen 15 nötr figürü de dansa ekleyerek toplamda 45 figürden oluşan bir dans tasarlar. Tasarladığı on duygunun dansını Natya Shastra metinlerinde tanımlandığı şekli ile günümüz Hint klasik dansı formatında canlandırır ve videoya kaydeder.

Hazırlanan bu videolar, Amerikalı ve Hintli kolej öğrencilerinden oluşan test grubuna izlettirilir. Katıımcılardan izledikleri 45 dans figürünün ifade ettiği duyguyu bulmaları istenir. Deney iki gruba farklı formatlarda uygulanır. Bir grupta bütün duyguların yazıldığı "sabit seçim formatında" yanıt kâğıdı, diğer grupta ise hiçbir bilginin olmadığı "serbest yanıt formatında" boş bir yanıt kâğıdı vardır.

Her iki ülkeden katılan ve sabit seçim formatında yanıt veren katılımcılardan beklenen doğruyu tahmin etme değeri \%9 iken bu değer beklenenin çok üzerinde \%65 doğru olarak gerçekleşir. Serbest yanıt formatında ise katıımcılardan sıfıra yakın beklenen doğru değer \%61 doğru olarak gerçekleşmiştir. Bu araştırma Hejmadi'nin çalışmasına katılan hem Amerikalı hem de Hintli denek grubundaki izleyicilerin dans yoluyla iletilmeye çalışılan duyguları anlama ve doğru tanımlama konusunda oldukça başarıı olduklarını otaya koymuştur. Birbirlerinden oldukça farklı kültüre sahip iki katıımcı grubunun da duyguları tanımlamakła zorluk çekmediği gözlemlenmiştir. 
Hejmadi bu çalışmaların sonuçlarını değerlendirdikten sonra dans için bir tanım daha ortaya koyar: Dans, kültürel bölünmeleri aşabilecek duyguları ifade etmek için güçlü bir iletişim aracıdır (Hejmadi, 2000).

Hejmadi'nin hazırladığı deneyden de yola çıkarak yapacağımız çıkarımda dans, kültürve dilkısıtlamalarını aşarakiki ayrıtoplum arasında ortak bağ kurabilecekleri etkili bir iletişim yolu olarak karşımıza çıkar. İlkel insandan beri var olduğu düşünülen dansın günümüz toplumuna ulaşmasının üstelik her toplum ve kültürde karşımıza çıkmasının sebebi, söz konusu bağ ve etkileşim olmalıdır. Bu sonuçlar ışığında dansın aynı zamanda bir iletişim şekli olduğu düşüncesini paylaşmak pek de yanıltıcı olmaz.

Benzer bir araştırma Türkiye' de de yapılmıştır (Çalışkan, vd. 2016). Ülkemizdeki araştırmanın çıkış noktası, tarihi ve kültürel değerlerin dans yoluyla topluma aktarımına ilişkin görüşlerin belirlenmesi olmuştur. Anadolu Üniversitesi bünyesinde hazırlanan bu kapsamlı çalışmanın amacı, bir bölgenin kültürel değerlerinin dans gösterisiyle izleyici topluluğuna aktarımına yönelik toplum görüşlerinin belirlenmesi olmuştur. Bu gösteri için izleyici motivasyonunun yüksek olduğu halk dansları seçilmiştir. Araştırmanın uygulandığı il Eskişehir olduğu için bölge kültüründen örnek üretmek düşüncesiyle yola çıkılmıştır. Antik çağlardan beri Porsuk nehri kıyısında yaşamış olan ve bu günlere büyük bir kültür zenginliği aktaran toplulukların tarihsel serüvenleri tema olarak belirlenmiştir. Araştırmanın temel konusu belirlenen bu temanın dans aracılığı ile izleyiciye ne ölçüde aktarılıp aktarılamadığı olmuştur.

Bu amaçla hazırlanan dans gösterisi, konusunu bölgeye hayat veren Porsuk nehrinden almaktadır, Porsuk nehrinin antik isminin "Tymbris" olmasından dolayı dans gösterisi "Tymbris'in Dansı" olarak adlandırımıştır. Bu araştırmanın katıımcıları, gösteriyi izleyenler arasından seçilmiş ve araştırmaya 714 kişi gönüllü olarak katılmıştır. Elde edilen veriler bilimsel yöntemlerle analiz edilmiştir. Bu analizlerin sonucu olarak "Tymbris'in Dansı" isimli gösteri Eskişehir'in tarihi ve kültürünün dans yoluyla topluma aktarımında ilgi çekici ve kullanılabilir bir yöntem olduğunu ortaya koymuştur. Araştırmacılar bu çıkarımı yayınladıkları makalede şöyle belirtmişlerdir (Çalışkan, vd. 2016, s. 336):

Sonuç olarak, "Tymbris'in Dansı" adlı dans gösterisinin Eskişehir'in tarihi ve kültürünën dans yoluyla topluma aktarımında ilgi çekici ve kullanılabilir 


\section{$\operatorname{arts}=$}

bir yöntem olduğu ortaya çıkmıştır. İzleyicilerin böyle bir dans gösterisini beğendiklerini ve Eskişehir'in tarihi ve kültürel değerlerini yeterli derecede anlattığını bildirmeleri; yerel, bölgesel veya ulusal tarihi ve kültürel değerlerin dans yoluyla anlatımının etkili olabileceğini göstermiş̧tir.

\section{SONUÇ}

Insanların çok farkı amaçlarla dans ettiklerini biliyoruz, bütün bu amaçlardan ortak bir payda çıkarmayı denersek çıkabilecek sonucun; hayatın getirdiği ya da getirebileceği olumsuz etkileri biraz kırabilmek, yaşamı bir nebze de olsa yumuşatıp daha yaşanabilir kılmak olduğunu söyleyebiliriz. Bunun dışında amacından bağımsız olarak sadece bir eylem olarak bakıldığında bile, insan bedeninden başka hiçbir enstrümana gerek duymadan yapılabilen dans sözsüz ve evrensel bir anlałım dilidir.

Dansın ortaya çıkışııı/doğuşunu araştıran geniş kapsamlı araştırmalar olmadığı gibi, yapılan çalısmalar da büyük ölçüde tahminlere dayanmaktadır. Günümüz bilim insanlarının çalışmalarında ve açıklamalarında insanların neden dans ettiği sorusunun cevabı da karşımıza net bir şekilde çıkmaz, genellikle tezler ve varsayımlar ile karşılaşırız. İnsanın neden dans ettiği henüz kesin olarak bilinmese de çağlar boyunca çok farklı amaçlar için birbirinden farklı dans türleri geliştirdiği ve bu dansları kültürünün bir parçası yaptığı ortadadır. Danslar kültürün bir parçası olurken, karşılıkı bir ilişkiyle kültürlere ait bazı izler de dansların yapısında kendilerini göstermektedirler.

Toplumlar arası kültürler ne kadar farklı olursa olsun dans hepsinin vazgeçilmezi olmuş, yaşamları içinde muhakkak var olmuştur. Kültürlerin çeşitliliği kuşkusuz danslarını da etkilemiştir ama bu etkileşim kültürel farkllıkların oluşłurduğu yeni danslar olarak tarihteki yerini almıştır. Üstelik bu danslar, içinde yeşerdiği topluluğun kültürüne ait izleri geleceğe taşıma nosyonunu da bünyesinde barındırmaktadır.

Dansa antropolojik açıdan bakıldığında içinde kültürel, tarihsel, yöresel mesajlar taşıdığı kolaylıkla görülebilir. Bu gösterge de dansın aynı zamanda geniş anlamda bir iletişim aracı olduğuna işaret eder. Bununla birlikte hemen her dansın özelde de bir hikayesi veya bir fikri vardır. Danstaki bu öznel mesajın aktarımı ise dansçının bedenini bir iletişim aracı olarak kullanabilmesiyle olasıdır. Dans ne kadar 


\section{$\operatorname{arts}=$}

kusursuz uygulanırsa içerdiği hikâye de o denli güçlü aktarılabilir. Dansın izleyiciyle olan ilişkisinin yanı sıra dans edenle de güçlü bir bağı vardır. Bu bağ dansı, dansçıyla iç dünyası arasında bir aynaya dönüştürebilirken, aynı zamanda iç dünyasını dışa vurabilmek için uygun bir araç haline de getirebilmektedir.

Bu makalede dansa sanat, ritüel veya bir sosyal etkinlik olarak değil, bir iletişim aracı olarak yaklaşılmıştır. Yapılan araştırmalar doğrultusunda, dansın izleyen üzerinde sadece sıradan bir devinim etkisi yaratmadığı aynı zamanda insanlar arasında etkileşim yaratan duygu aktarımı yolunu kullanan bir ifade biçimi olduğu sonucuna varımışır. Daha da önemlisi dansın insanları ırk, din, dil gözetmeksizin ortak bir fikirde, düşüncede buluşturabilen önemli bir köprü olduğu saptanmıştır.

\section{KAYNAKÇA}

Akgül, P.K. (2006). Kişilerarası Illetişimde Dans ve Beden Dili işlevini etkileyen Etmenler ve Bir Alan Araştırması. (Yayınlanmamış Doktora Tezi). Konya T.C. Selçuk Üniversitesi Sosyal Bilimler Enstitüsü, Halkla Illişkiler ve Tanıtım Anabilim Dalı, Halkla İlişkiler Bilim Dalı: Konya.

Akgül, P.K. (2014). İletişim, Dans ve Beden Dili. İstanbul: Cinius Yayınları.

Aktaş G. (1999). Temel Dans Eğitimi. İzmir: Ege Üniversitesi Basımevi.

Altunay, E. (2014). Paganizim - 1 Kadim Bilgeliğe Giriş (2. Baskı). İstanbul: Hermes Yayınları.

Aristoteles, (2017). Poetika Şiir Sanatı Üzerine (3. Baskı). İstanbul: Say Yayınları.

Bilican, R. (2019). Hindu inançlarında dansın yeri: "Dansın kralı Şiva". Türkiye Din Eğitimi Araştırmaları Dergisi, 8, 57-68. https://dergipark.org.tr/tr/pub/tudear/ issue/51238/667015.

Boas, F. (1972). The Function Of Dance in Human Society. New York: Dancehorizons.

Borg, J. (2008). Body Language. London: Pearson Education Limited.

Communication, (2020). Online Etymology Dictionary. https://www. etymonline.com/ word/communication. 


\section{$\operatorname{arts}=$}

Çalışkan, D. Batmaz, Ö. Taşcı, P. Şenbayram, Ö. Tuncer, O. Akalın, Ö. Erkoçak, Ö. Feratan, Ö. Uluyol, A. (2016). Tarihi ve Kültürel Değerlerin Dans Yoluyla Topluma Aktarımına İlişkin Görüşlerin Belirlenmesi: Eskişehir'in Tarihi ve Kültürel Değerlerinin Anlatımında "TYMBRIS'IN DANSI". Anadolu Üniversitesi Sosyal Bilimler Dergisi, Cilt: 16 Sayı: Özel Sayı, 319-340. DOI: 10.18037/ausbd.417483.

Dingfelder, S. F. (Nisan 2010). Dance, Dance Evolution. (Erişim Tarihi 27.07.2019) https://www.apa.org/monitor/2010/04/dance.

Eroğlu, T. (Aralık 2017). Dans Kavramı ve Dansın Işlevi. The Journal of Academic Social Science Studies S. 60 :215-226. DOI: 10.9761/JASSS6998.

Ehrenreich, B. (2006). Dancing in the Streets. New York: Metropolitan Books.

Hejmadi, A. (Haziran 2000). Exploring Hindu Indian Emotion Expressions: Evidence for Accurate Recognition by Americans and Indians. (Erişim Tarihi 19.07.2019) DOI: $10.1111 / 1467-9280.00239$.

Kaeppler, A. L. (2006), Dans (Çev. F. K. Fay), Halkbiliminde Kuramlar ve Yaklaşımlar 1 (s. 406-411). Ankara: Geleneksel Yayıncılık.

Keehn R. Joanne J. Patel D. A. Iversen R. John, S. I. (2019). Spontaneity and diversity of movement to music are not uniquely human. 29(13): R621-R622, DOI: 10.1016/j.cub.2019.05.035.

Kline, N. M. (1975). Enjoying The Arts: Dance. New York: R. Rosen Press.

Koçkar, M. T. (1998). Çağlar Boyunca Beden Dilinde Sanat ve Kültür Illetişimi Dans ve Halk Dansları. Ankara: Bağırgan Yayınevi.

Özgüven, İ. E. (2010). Ailede İletişim ve Yaşam. Ankara: Pdrem Yayınları.

Öztürk, A. (2014). İletişim Sistemleri ve İletişim Teorisi. Selçuk İletişim, 1 (1), 5869. https://dergipark.org.tr/tr/pub/josc/issue/18999/200896.

Patel, A. D., Iversen, J. R., Bregman, M. R., \& Schulz, I. (2009). Experimental evidence for synchronization to a musical beat in a nonhuman animal. Current biology: CB, 19(10), 827-830. https://doi.org/10.1016/j.cub.2009.03.038.

Royce, A. P. (1980). The Anthropology Of Dance, Bloomington. Indiana: University Press.

Tercan, C. (2016). Topluma Katıım Aracı Olarak Dans. (Yayımlamamış Yüksek 
Lisans Tezi). T.C. Balıkesir Üniversitesi Sosyal Bilimler Enstitüsü Sosyoloji Anabilim Dalı, Balıkesir.

Wiltermuth, S. S., \& Heath, C. (2009). Synchrony and Cooperation. Psychological Science, 20(1), 1-5. https://doi.org/10.1111/j.1467-9280.2008.02253.x. 